\title{
HANS KRÜGERS \\ SAMTIDIGE I HADERSLEV VESTERAMT
}

AF

M. REFSLUND POULSEN

GAARDEJER, BOVLUND

$+$

$\mathbf{Z}^{\text {or }} 4^{0}-50$ Aar siden sagde de gamle i den sydlige Del af Haderslev Vesteramt om Egnen syd derfor: „Ovre i Hertugdømmet“. At de statslige Forhold i nogle Aartier havde været ens, havde ikke været i Stand til at udviske den Forskel i Folkekarakteren, som en lang Fortids Forskellighed i politiske og økonomiske Levevilkaar havde udviklet.

Det er ingen Tilfældighed, at man i vistnok ingen Del af det danske Rige er saa „kongelig sindet" som i den tidligere „kongerigske“ Del af Sønderjylland. Fra Frederik d. II.s Tid sad Bønderne i et saa frit og billigt Arvefæste, at det grænsede nær til Selveje. Haderslev Vesteramt har siden den Tid kun haft et Gods, Gram, hvor til Gengæld en af de værste Herremandsrettigheder holdt sig saa længe, at min i 1840 fødte Fader har været med paa Hoveri der. Det var kun den lille Undtagelse, der yderligere fremhævede de lykkelige Kaar, som de danske Konger skabte for deres Bønder, hvor Kongen var Hertug.

„Den kongerigske Del“ var selv under Enevælden i højere Grad end det øvrige Land Kongens personlige Ejendom. I den blev de Forbedringer, man agtede at indføre, først prøvet. De store Landboreformer kom først hos os. Lovene om Udskiftning og „den store Landbokommission “ fik vi io Aar før det øvrige Land. Dette Gode har rigtignok ogsaa medført en Ulempe. Overalt har det vist sig, at de tidlige Udskiftninger var de lemfældigste, de daarligste. Først efterhaanden vandt man Mod til at gaa radikalt til Værks. Virkningen af dette strækker sig til den Dag i Dag, idet det er en af Grundene til, at mange Egne af Sønderjylland har en saa spredt Beliggenhed af Landejendommenes Jorder.

I de trange Tider efter Statsbankerotten kom Nøjsomhed og Arbejdsomhed i Højsædet. Og disse Egenskaber holdt sig, efter at Tiderne omkring I83o langsomt havde bedret sig. Ja de holdt sig endog, efter at Tiderne var blevet gode. 
Min Moster var som lille Pige, skønt Datter fra en stor Gaard i Bovlund i NørreRangstrup Herred, først i Fyrrerne med til at køre Mergel fra Morgen tidlig til Aften sent. Nu gav det Penge paa Kistebunden. Skønt det var svært at afse Dalerne, havde man let ved at udrede det forholdsvis lille Beløb, der skulde til for at købe sig fri for Fæstet, der blev afløst i de Tider. En god 5 Ottings Gaard i Bovlund blev i 1857 afløst fra Fæstet til fuldt Selveje for 339 Rigsdaler. En anden Ottings Fæsteejendom afløstes i 1860 for 47 Rigsdaler.

Men ellers gjaldt det om at holde paa Skillingerne, saa man kunde faa samlet en Sum til de Børn, der ikke som den ældste Søn fik Gaarden. For det var Hævd og Lov, at den ældste Søn skulde have Gaarden helst kvit og frit med Undtagelse af en rundelig Aftægt til de gamle. Aftægten var jo i Naturalier og Pleje; kun et ganske lille Beløb til Haandpenge aarlig. Der blev spottet over de magre Byer, der kun kunde give en smal Aftægt. Endrupskovs Aftægt var vidt og bredt bekendt. Endrupskov ligger jo paa en Bakke, ved hvis Fod der løber en Aa. Dets Aftægt skulde bestaa i, at de gamle blev sat paa en halv Vogn med et Brød og et Pund Tobak, og saa kunde de trille ned i Aaen. Tyendet blev paa Gaardene i Aartier, ofte hele Livet paa et Sted. Som Dreng har jeg hørt en gammel Arbejdsmand fortælle om, hvor bange de for Ioo Aar siden var for ikke at faa Lov til at blive paa Gaarden. Forblev Tyendet ugift, og mange baade af Tyende og Gaardfolks Børn giftede sig ikke, saa kunde det blive „flegfør“. En Flegfør betragtedes som hørende til Familien, om end stadig i en noget underordnet Stilling, hjalp, saa længe de kunde, havde senere, endog retslig efter jydske Lov, Krav paa Pleje og en hæderlig Begravelse. Til Gengæld tilfaldt alt, hvad Tyendet havde opsparet, Gaarden. I det Tidsrum, jeg har afgrænset ved Overskriften, var den sociale Modsætning mindre end nu, men Forskellen nærmest større. Da en Gaardmandskone sagde til en gammel Arbejder: „Naar Bønderne har Penge, saa har alle Penge, “ svarede denne: „Vi har aldrig havt det saa smaat, som da Bønderne havde deres gode Tid.“ Hvad Bønderne skulde sælge, steg, men Udgifterne, blandt andet til Folkehold, fulgte kun langsomt efter, saa det blev en stræng Tid for Smaafolk. Arbejdstiden var lang og Lønnen lille - i de Kredse var der ikke Overskud af Kraft, saa man kunde tænke paa andet end Stræbet for Føden. Mange satte Kulør paa Tilværelsen med Brændevin. Fra „Smaafolkene“ hørte man intet. Tiden var Bøndernes.

Naar den ældste Søn fik Gaarden, blev de rede Penge delt mellem de øvrige Børn saaledes, at Sønnerne fik en Broderpart, der var det dobbelte af en Søsterpart. Desuden fik de Børn, der blev udskiftet fra Stavnen, noget Udstyr. Da Hans Refslund i Bovlund i 1828 fik den 5 Ottingsgaard efter Forældrene, skulde 
han foruden Aftægten betale 2500 Rigsbankdalere eller I 333 Daler i Sølv og til sin Broder „en sadlet Ridehest, tilligemed en Kiste og 3 de forsvarlige Klædninger". Og til sine to Søstre hver „et Shatulle med Skab, 2de Kister, $\mathbf{1}^{1} / 2$ forsvarlig Seng, et Slagbord, et lidet Bord, 2de Spejle, 9 Stole, 3de Klædninger, nemlig en sort og 2de kulørte. Iøvrigt forbeholdes alle 3 Søskende, saa længe de er i ugift Stand, at have ved Stavnen fri Tilflugt, med Husværelse, Seng, Ild og Lys". Hans Refslund var saa meget Fremskridtsmand, saa da han i I 847 deler med Børnene, skal den ældste Søn have Gaarden mod at udbetale Broderen og Søsteren hver 2000 Daler curant, desuden maa Broderen efter eget Valg tage en sadlet Ridehest, medens Søsteren skal have den afdøde Moders Kister og Sengeklæder (formodentlig dem, hun har bragt til Stavnen). Da Hans Refslund dør i samme Aar, er der 2500 Daler efter ham, som Retten deler med rooo Daler til hver af Sønnerne og 500 Daler til Datteren.

Et andet Sted fik ved Midten af Aarhundredet Sønnen Gaarden, medens de to Søstre delte de rede Penge, 2000 Daler, der var til Gaarden, og hver fik desuden et Udstyr.

Det kunde ske, at en yngre Søn kunde faa en Udmark til en ny Gaard, men det var kun sjældent, og Arveparten blev ikke stor nok til at købe sig en Gaard, for helst hele Købesummen skulde udbetales. Det var vel muligt at faa et Laan indprotokolleret, f. Eks. fra en af de ikke faa Bønder, der havde tjent Penge paa Kreaturhandelen - men, som en gammel Bonde sagde: Skal man have Halvdelen til Gæld, saa duer det ikke at være Bonde. Da Guldfundene skete i Kalifornien og Australien, rejste en Del af de yngre Sønner dertil for at prøve Lykken, men efter et Par Aars Forløb kom de hjem igen i hvert Fald rigere paa Erfaring og Fortællinger - og fortsatte saa Livet igennem paa Hjemstavnen. For de ugifte Søskende blev ofte gaaende i Hjemmet, og denne Skik holdt sig saa længe, saa jeg har kendt adskillige Steder, hvor der gik 2 til 3 ugifte Søskende hjemme hos den som oftest gifte Broder, der havde Hjemstavnen. De blev i Folkemunde ved at hedde Piger og Drenge, selv om de blev gamle Folk.

Naar det saa som oftest traf sig saa heldigt, at den ældste Broder blev „godt" gift, for det havde han Chancer for, vil man kunne forstaa, at Gaardmanden med de opadgaaende Tider kunde blive velstaaende. Senere Tider har fundet denne Arvedeling ubillig og derfor ændret den. Imidlertid har den været grundlæggende for den økonomiske Styrke, vor Bondestand fik, og stærkt medvirkende til den Karakter og det Sindelag, der udvikledes.

De opadgaaende Tider og Arvedelingen var jo ikke noget særligt for den kongerigske Del af Sønderjylland, men til dette solide Grundlag kom saa det 
særlige, at man sad paa sit eget, hvor ens Fædre havde siddet gennem mange Slægtled, - som disse følte man sig fri og uafhængig. Velstanden gav et Overskud af Kraft. Man blev svært „kaalhøgen“. Over disse Folk kom saa den nationale Opvaagnen i Fyrrerne, som gav dem aandelige Interesser. Den udløste en Trang, de nu havde, den til at protestere. Man protesterede mod Tyskeriet, mod Embedsmændene. De Folk, der kom for ved Midten af det nittende Aarhundrede, løftede Hovedet højere end deres Fædre, der først og fremmest havde slidt og samlet Penge. Nu havde man Raad til andet ogsaa. Naar den unge Bonde, Bunde Refslund skriver i sin Dagbog: „I Morgen skal vi køre Rug ind, og saa kan jeg ikke komme over at se til Ingeborg. Bare det vilde give Regn!" saa er han langt fra Faderen, først med i det hele taget noget saa unødvendigt som at føre Dagbog og saa med det letsindige Ønske.

Forældrene havde vel nok kunnet læse og skrive, men ikke, saa de var Herre over det - først dette Slægtled fik fuldt Magten over Pen og Bog. Vi, der har Færdigheden som en Selvfølge, har let ved at glemme, hvilken Landvinding det var. "Spidserne", som vi nu har lettest ved at kigge i Kortene, skrev - i Modsætning til selve Høvdingen, Krüger - let, godt og meget. Fra de gulnede Blade slaar det én i Møde, hvilken Svir Skriveriet har været for dem. Gaardejer Thomas Høyer i Agerskov skrev Dokumenter for hele Sognet - Aftægtskontrakter, hvori intet var glemt, og i Fattigprotokollen kan man endnu læse, hvad de forskellige Fattiglemmer har vidnet, da en Strid mellem dem skulde bilægges paa Sognets Fattiggaard. Da den nordslesvigske Landboforening for nogle Aar siden holdt 75 Aars Jubilæum, blev Forhandlingsprotokollen fremdraget, og der blev gjort opmærksom paa, at i de første Aartier skrev man meget mere end nu. Som Eksempel paa, hvor grundigt man noterede, blev der nævnt et Referat af et Foredrag om Emnet: Hvornaar er Ajlen tjenlig til Udkørsel?, som havde til Resultat, at den var tjenlig til Udkørsel, naar den slog Blærer. Bunde Refslund, der nitten Aar gammel som ældste Søn efter Faderens Død i I 847 maatte overtage en Gaard i Bovlund, fører i 1850 en Dagbog, der viser en overordentlig Evne til at udtrykke sine Følelser skriftligt. Indholdet har ikke direkte almen Interesse, idet den kun handler om den gamle Historie: hans Glæde over Ingeborg. Ved Siden af viser den hans Belæsthed, hovedsagelig den danske Romantik men ogsaa Goethe og Schiller. Da de havde været til Barselgilde paa Oksgaard, skriver han: „I Aftes vilde Musikanteren og Kone nok have kjørt med, men saa vare vi begge to meget bange for at kjøre den daarlige Vej, daarlig fordi den var saa kort, og fordi vi saa ikke vare ene sammen; altsaa kjørte vi den bedre Vej efter Mellerup. Jeg tænker Freia selv har styret Hestene, at de fulgte 
Vejen, thi hvor var det vel muligt for mig at passe saa nøje paa dem, naar jeg sad med den ene Arm slynget om Ingeborg med den anden Haand $i$ hendes." Et andet Sted skriver han: „Her er ingen Bera, som hindrer Signe fra at elske sin Hagbarth." Han og mange andre af Spidserne havde først gaaet i den dygtige men tørre Folkeskole, som stammede fra Rationalismen, og var saa som ung kommet paa Rødding Højskole. Rødding Højskole prægede dette Slægtled stærkt, og vi maa huske paa, at den havde en anden Karakter end de af Kold paavirkede Højskoler, som vi kender. Det viser blandt andet de af Skrumsager nedskrevne Erindringer fra Opholdet. Den var paavirket ikke alene af Romantikken men ogsaa af Nationalliberalismen. Den gjorde mere end vor Tids Højskoler for at gøre Eleverne "dannede" og kundskabsrige, mere for at skærpe deres Forstand. Mange af Eleverne var der i 2 Halvaar, og de blev prægede af Opholdet for Livstid.

Der var særlig 2 Mænd udefra, som senere virkede i koldsk Retning: Chr. Sigfred Ley og Morten Eskesen. Sigfred Ley blev jo Kolds Efterfølger som Huslærer hos Knud Knudsen i Forballum og senere paa Trøjborg. Med dem var Forbindelsen livlig, og Ley kom ogsaa senere som Huslærer til Bovlund. Der læste han „Hakon Jarl“ for dem, „saa Haarene rejste sig paa deres Hoveder", og instruerede dem til at spille "Jeppe paa Bjerget". Morten Eskesen opholdt sig en Tid hos Hans Krüger i Bevtoft, og senere kom han flere Gange om Aaret rundt til forskellige $\mathrm{Hjem}$, hvor han fortalte, sang Kæmpeviser og lærte dem nye Melodier til de nationale Sange. De fik dannet „Danske Samfund“ (i min Saxo staar: Til Danske Samfund i Agerskov og Omegn fra N. F. S. Grundtvig) og gav Stødet til Folkefesterne i Mandbjerg Skov, hvor der blev talt og sunget ud fra det stærke folkelige Røre.

Naar de „Danske Samfund“, Mandbjerg Festerne og en enkelt Folkefest paa „Hyholm“ er nævnt, saa er man i det væsentlige færdig med Foreningslivet og Møderne. Det var ikke nær nok til at rumme den nyvakte Sans for Danskheden. Datidens mange, store Gilder blev til folkelige Fester. Ved Bryllupper, Barselgilder, Julegilder, „Flythøtter" og „Rejshøtter" blev der talt og sunget om Kærligheden til Land og Folk. Man mødte til dem med hele den første Generations glubende Appetit, Oplagthed til at more sig, til at synge, tale og høre. Nu har vi det mere praktisk ordnet med at faa Gæsterne ved Gildet paa ret Plads. Den Gang havde Skafferen en stræng Post med at faa Gæsterne til Bords. Det hørte til god Tone at skulle lade sig slæbe til Bords. Endnu i min Barndom har jeg set 2 Skaffere komme slæbende med den beskedne, der greb om Dørkarmen, saa der sprang en Knap. Besværligt og tidsspildende var det, men man morede sig ved 
det. Naar man var færdig med at spise, tale og synge, morede man sig, hvis Vejret tillod det, i det fri med Lege, som ældre nu ikke vilde deltage i. Da jeg for godt 50 Aar siden for første Gang var med til et Begravelsesgilde, saa jeg Bønderne „snare Gæs" ude i Toften, „slaa Kokken af Hønen“" og skiftes til i en Balje at trille ned ad Skrænten. Ved saadanne Lejligheder kunde den sønderjydske Form for Humor, Drilleriet, rigtig faa Lejlighed til at udfolde sig. Det var ofte skarpt og kunde blive grovkornet. En Gaardmand fik fra en Ven sendt en Juleforæring, som han mente var en Kasse Gigarer. Noget efter Jul blev der saadan en ækel Lugt i Huset, som endelig blev sporet hen til Cigarkassen. Den indeholdt fint indpakket Kød fra et Rævekadaver. Da en Gang nogle af Egnens Spidser skulde vise deres Upaavirkethed af Gildets Spiritus ved at køre derfra staaende i en Kassevogn, drillede en af de største „Spolte“ en af de andre med at besørge et lille Ærinde $i$ hans aabentstaaende Frakkelomme. Den Streg blev der lét godt af, men man var i det offentlige saa pæne, saa det vilde have været umuligt at se den paa Tryk.

Ved Gilder og Besøg og for Resten ogsaa til andre Tider blev der nydt megen Spiritus - maalt med vor Tids Alen. Det tidligere Slægtled drak meget mere. Jeg har hørt gamle Folk fortælle om, at da de var Børn, brændte Bønderne selv Brændevin i Smug, og saa gik de rundt og smagte til Pas paa Varerne, saa hele Byen blev drukken. Selv om det i Forhold dertil var Fremgang i \&drueligheden, saa blev der dog brugt meget af stærke Drikke. Mange af Førerne og i mindre Grad Underhøvdingerne fik mere af Spiritus, end de havde godt af. Selv om de ikke blev drukne (hvilket ogsaa kunde ske, saa de maatte bæres til Vogns) saa blev de i løftet Stemning - det stemte med, som de i det hele var indstillet paa det højtsvungne. Der var noget vist storladent over Tiden. Førerne havde en vældig Kraft - baade i godt og ondt. Man maa sige, at der viste Menigmand at have næmmet noget af Tidens Storsind. Vel var man naturligvis ikke glad ved, at der var noget at sige dem paa, men man var forstaaende nok til at fatte, at var de store $\mathrm{i}$ deres Lyssider, saa maatte man bære over med, at de ogsaa havde store Skavanker.

Det Slægtled, der her er Tale om, var i økonomisk Henseende anderledes indstillet end dets Forældre. De havde Bevidstheden om, at de var velstillede, og det medførte, at Forældrenes Sparsommelighed og Arbejdsomhed ikke blev taget i Arv. Der er jo Mennesker, som har en saa stor Arbejdslyst og Trang, at de er flittige, hvordan end Forholdene ligger - men mangen Bonde holdt op med det legemlige Arbejde, da Nødvendigheden ikke mere tvang ham. Jeg har kendt mange Bønder af det Slægtled, der førte en meget magelig Tilværelse - 
i Modsætning til Kvinderne, der som Regel sled bravt i det, tit endog over Evne. Velstanden gav sig ogsaa Udtryk i Byggeri - og særlig af den uproduktive Del, Stuehuset. En Bonde paa en middelstor Gaard byggede sig i I 866 et nyt Stuehus paa $25 \times 10,5 \mathrm{~m}$ med Skifertag, to Kviste og Takker paa alle Gavle og med en Loftshøjde af 3,I5 m. Der siges, at han skrev op, hvad det kostede, men „han blev led ved det, da han kom til 6000 „Preusere“". Altsaa 18000 Mark = I60oo Kroner. Udbygningerne var det, man sidst tog fat paa, hvilket stemte godt med, at selve Landbrugsbedriften ikke i saa høj Grad havde deres Interesse, og de var ikke saa dygtige deri, som det tidligere Slægtled — og det, der kom efter. Der udfoldede sig efterhaanden en rund og storslaaet Gæstfrihed, og ogsaa megen Selskabelighed. Naar man saaledes tit kom sammen, nøjedes man ikke med en Kaffevisit; man kom til Eftermiddagskaffe, fik varm Aftensmad, Toddi og Aftenskaffe med et Utal af forskellige Slags Kager til. Hvad enten man som i visse Kredse spillede Kort eller ej, saa forte man en livlig Samtale - ofte Forhandling. Sjælden om Landbrug, for vor Tids levende Interesse derfor havde man altsaa ikke, undertiden om Egnsnyt, men oftest om det, der brændte i dem: de nationale, folkelige og kirkelige Spørgsmaal. Der var Fest over Sammenkomsterne.

Skønt Salgsprodukterne steg og Driftsudgifterne kun fulgte langsomt efter, saaledes at det var en glimrende Landbrugstid, saa satte adskillige Gæld. At det gik de store Førere økonomisk daarligt, var en Selvfølge, for de ofrede Tid og Penge for Sagen, og den Gang blev offentligt Arbejde ikke betalt. Gang paa Gang maatte der derfor samles ind til dem, for at der ikke skulde ske Krack. Men ogsaa adskillige af de andre viste sig ikke at have faaet det økonomiske Udbytte af den langvarige gode Tid, som der var Grund til at vente. Da Landbrugskrisen omkring $1880 \mathrm{kom}$, bukkede mangen én under, der som ung havde faaet Gaarden for lidt eller ingenting og maaske endda Penge til med Konen. Prisfaldet paa Salgsprodukter og Landejendomme var stort - men man kom nogenlunde over det af forskellige Grunde. Realkreditten og andre Kreditmuligheder var endnu saa svagt udviklet, at man kørte i Staa, før Gælden naaede op til Salgsværdien, selv efter Ejendomsprisfaldet. En stor Gaardmand kørte i Staa med Driften, lejede saa megen Jord ud, saa han kun havde I Hest og et Par Køer, og saa indbragte Lejen ham saa meget, at han kunde betale Renterne og de smaa Skatter og endda have en pæn Skilling til at leve for. En anden noget mindre men dog stor Gaard bragte ved samme Fremgangsmaade vel ikke ligefrem Penge over, men Vedkommende beholdt til egen Udnyttelse Jord til 2 Heste og 20 Kreaturer uden Afgift. To middelstore Gaarde kunde hjælpe sig 
igennem paa lignende Vis. En maatte sælge men fik dog, saa vidt jeg ved, 4000 Mark tilovers. Disse Eksempler, som er taget i en Mils Omkreds, kunde ved nærmere Gennemgang sikkert forøges med flere lignende. De, der gik fra Gaardene, havde flere Muligheder. Byerne var ikke overfyldte, saa der kunde der findes en eller anden beskeden Tilværelse. Dér saavel som paa Landet var der en Vej at slaa ind paa, som var lønnende og meget benyttet. Man kunde blive Gæstgiver, saa éns Gæstfrihed i Stedet for at tage Penge, kunde blive en Indtægtskilde. Der var nemlig god Brug for mange Gæstgiverier, for der var jo ingen Baner i Haderslev Vesteramt, og Vejene var gennemgaaende daarlige, men man benyttede dem flittigt, saa Heste og Folk trængte til at komme til Kro's.

Man kørte saa meget, dels fordi man før Krisen havde Tid og Raad til at køre, dels fordi man skulde have Slægtninge og Bekendte besøgt, men ogsaa fordi det nu en Gang fulgte med den Maade, hvorpaa et Spørgsmaal blev taget op og løst. Jeg har nævnt, at man tidlig fik „Danske Samfund“, som betød ikke lidet, men det synes, som man endnu ikke var moden til Foreningsliv, for de sygnede snart hen, og det, som vi nu ordner ved Hjælp af vore Foreninger og Institutioner, havde en saa at sige mere frivillig og tilfældig Vej at bane sig fremad. I Stedet for vore vidt omspændende Organisationer, der fatter og udfører Beslutninger, havde de et mindre demokratisk Raad, et Slags ikke regelbundet Frimureri mellem alle Spidserne, som var dem, der sagde, hvad der skulde ske, og sørgede for, at det skete - det sidste rigtignok i meget mangelfuld Form. Naar et Spørgsmaal trængte sig paa, saa var det ikke ved Organisationen paa Forhaand givet, at den og den skulde tage sig af det, nej, den som saa, hvor Tampen brændte, spændte for og kørte hen til den nærmeste Bykonge og tog ham med til den næste. Man regnede ikke at køre 5-6 Mil paa en daarlig Vej. Som Morten Eskesen gik „paa Kongens Togt", naar han sang og talte om den danske Folkeaand, saaledes kørte Spidserne milevidt paa Kongens Togt for at pleje Raadslagninger. Og man skrev lange Brevvekslinger. Saaledes er de kendte Adresser og Deputationer kommet i Stand, og saaledes er Kandidaterne til de forskellige Valg blevet opstillet. Set med vore Øjne er det forbløffende, saa lidt der blev gjort af Valgagitation, endsige for en Plan for denne. At der var saa liden Lyst i den Retning, hænger sammen med hele deres Sindsindstilling. De var - af Natur og Arv saavel som fra den historiske Udvikling - Individualister, "Protestanter" om en Hals. Men ved „den nationale Opvaagning" og Begivenhederne i 1848 var de i Følelse og Overbevisning blevet begejstret for 
det fælles Folkelige. Denne Modsætning gav en Spænding i deres Sind, som maaske netop har virket til rig Vækst og Udfoldelse.

Da nogle Børn af en mere nøgtern Tid kom hjem fra et Sted, hvor de havde hørt den gamle Morten Eskesen fortælle og synge, berettede de, at han havde haft én med, men han maatte vist være bleven i Forstuen, for de havde ikke set ham. Forældrene gik dem nærmere paa Klingen med, at de dog maatte huske, hvad han i Forstuen hed, og da viste det sig, at det var "Aanden“. Det var imidlertid ikke alene Morten Eskesen, der havde Aanden med sig, ogsaa for de andre var den danske Folkeaand en Realitet, som var lige ved at tage Kød og Blod. Selv om vi andre ogsaa tror, at der er en dansk Folkeaand, saa er vi dogikke paa samme Maade Dus med den, som de var.

Ved Gilder, Fester og Besøg blev der tit talt om „Retten“. Den var næsten selvvirkende ved sin Kraft af Sandhed og som Udtryk for Forsynets Vilje. Holdt vi kun fast ved vor hellige Ret, saa skulde det nok vise sig, at selv om Jætterne kunde have Overtaget en Tid, saa skulde Sandhed og Retten nok sejre tilsidst. Og dermed kom man til et tredie af de Begreber, som tit har varmet deres Sind: Haabet. Det blev der efterhaanden talt allermest om. Det skulde holde én frisk, indtil Retten sejrede. Alt blev talt og sunget ud af en højspændt Idealisme. I 1888 spurgte en ældre Mand mig, der var Knøs, om jeg vilde udvandre eller gaa tysk Soldat. Jeg svarede, som jeg saa tit havde hørt i mit $\mathbf{H j e m}$, at hvis vi ikke blev, saa vilde Tyskerne hurtig faa Danskheden ud af Nordslesvig. Skønt han ellers havde forliget sig med den nye Tids Krav, saa vendte det sig dog $\mathrm{i}$ ham, og han sagde saa heftig, som om han havde set Hans Krügers Skygge: „Hvis Sønderjyderne aldrig havde bøjet sig det mindste og aldrig havt med Tyskerne at gøre, saa var de blevet nødt til at give Sønderjylland tilbage, for en Stat kunde ikke have en øde Landsdel liggende. " Det var et Udslag af den Naivitet, som gjorde den Tids Mennesker samlede og stærke, men ogsaa hjælpeløse, da de tørnede sammen med en anden Tidsaand - den Bismarck havde skabt. Vilde én have hævdet, hvad nu er Skolemad, at den politiske Kunst bestaar $\mathbf{i}$ at faa det bedst mulige ud af den givne Situation, saa vilde Hans Krügers. Disciple, som vel nok gik videre end han selv, have spyttet det onde fra sig og sagt: Nej, sætte sig et Maal og stile lige mod det uden Sideblik til andre - det er en Mand værdigt! Saadan maatte de jo være indstillet. Foruden den ældre Indvirkning af Historien - det særlige slesvigske og inden for dette igen det særlige for den kongerigske Del - stammede de fra Romantikken og „Aanden fra Otteogfyrre“. Og da man havde det højtidelige Løfte i $\S 5$, saa kunde det. 
jo ikke vare ret længe, inden Grænsen atter blev flyttet. Der var kun at kræve sin Ret og haabe og vente paa bedre Tider.

Under denne Venten bredte der sig efterhaanden Mismod. Et Slægtled var udvandret - der manglede Ungdom. Det trøstesløse i Tilbagegang magtstjal.

Krüger mødte Bismarck. Og det gik, som det altid gaar den, der har forældede Vaaben. Et Slægtsleds Anskuelser og Sindsindstilling havde, - hvor velbegrundet det end til sin Tid havde været - nu overlevet sig selv, saa det blev som at sejle med Lig i Lasten. Da den ny Tids ændrede nationale Kampmaade, hvis første Mand H. P. Hanssen blev, kom, maatte meget af det gamle ændres. Mange af os, der den Gang var purunge, syntes, at de gamle ikke havde Øje for, hvad Tiden krævede. Den Gang havde vi ofte svært ved at yde dem den Retfærdighed, de har Krav paa. For som en Mand kan forlange ikke blot at huskes som Olding, men at mindes som han var i sin Manddoms Kraft, saaledes har Hans Krügers samtidige et berettiget Krav paa at mindes som den storladne, af Land og Historie groede Slægt - som den var, da den var paa sin rette Plads i Tiden - og ikke kun fra, da den havde overlevet sig selv. 